\title{
PRODUKTIVITAS PASTURA CAMPURAN PADA BERBAGAI TINGKAT NAUNGAN DAN LEVEL PEMUPUKAN
}

\author{
Mixed Pasture Productivity at Different Levels of Shade and Levels of Fertilization
}

\author{
Maradona Barutu ${ }^{1}$, Nevy Diana Hanafi ${ }^{2}$, dan Usman Budi ${ }^{2}$ \\ 1) Mahasiswa Program Studi Peternakan Fakultas Pertanian Universitas Sumatera Utara, \\ 2) Staf Pengajar Program Studi Peternakan Fakultas Pertanian Universitas Sumatera Utara
}

\begin{abstract}
The purpose of this study was to determine the response of pasture mixtures at various levels of shade and fertilization on forage production (dry matter), and nutrition. The method used Split-split plot design, where the main plot is the shade (without shade, shade by shade density of 1,7 $\mathrm{mm}$ and 0,2 $\mathrm{mm}$ density), the subplot was the level of fertilization (T0: without fertilization, and T1: $100 \mathrm{~kg}$ Urea $+50 \mathrm{~kg} \mathrm{SP-36}+50 \mathrm{~kg} \mathrm{KCl} \mathrm{per}$ hectare), and the sub-sub plot was pasture, consisting of (P0: Arachis glabrata + Calopogonium muconoides + Centrocema pubescens. P1: Stenotaphrum secundatum + Brachiaria humidicola + Pueraria javanica + Arachis glabrata, P2: Stenotaphrum secundatum + Brachiaria humidicola + Pueraria javanica + Calopogonium muconoides and P3: Stenotaphrum secundatum + Brachiaria humidicola + Pueraria javanica + Centrocema pubescens). The results showed that the dry matter productivity were not significantly different effect on the level of shade and fertilizer levels. Highest dry matter results found in N2T1P1 is equal 1.7065,60 $\mathrm{kg} / \mathrm{ha} /$ year. Meanwhile, crude protein contents gave different effect, where the highest crude protein content in treatment N2T1P1 (19,51\%). The crude fibers were influenced by treatments, where the highest crude fiber content in treatment NOTOP2 (42,49\%). The crude fat were influenced by treatments, where the highest The crude fat in treatment N2T1P1 (4,07\%).
\end{abstract}

Keywords: Productivity of pastures, pasture mixture, shade, fertilizer, nutrition.

\begin{abstract}
ABSTRAK
Penelitian ini merupakan langkah untuk mengatasi masalah lahan yang sempit yaitu dengan cara meningkatkan produktivitas hijauan yang lebih berkualitas dengan pengaruh unsur hara pada tanaman dan pengaturan sinar matahari langsung ke tanaman. Tujuan penelitian ini adalah untuk mengetahui respons pastura campuran pada berbagai tingkat naungan dan pemupukan terhadap produksi hijauan (bahan kering), dan kandungan nutrisi,. Metode penelitian yang digunakan adalah rancangan petak-petak terbagi (Split-split Plot), dimana sebagai petak utama adalah naungan (tanpa naungan, naungan dengan kerapatan 1,7mm dan naungan dengan kerapatan 0,2 $\mathrm{mm}$ ), anak petak adalah level pemupukan (T0 : tanpa pemupukan, dan T1: 100kg Urea + $50 \mathrm{~kg}$ SP-36 $+50 \mathrm{~kg} \mathrm{KCl}$ per hektar), dan anak-anak petak yaitu pastura yang terdiri dari (P0: Arachis glabrata + Calopogonium muconoides + Centrocema pubescens. P1: Stenotaphrum secundatum + Brachiaria humidicola + Pueraria javanica + Arachis glabrata, P2: Stenotaphrum secundatum + Brachiaria humidicola + Pueraria javanica + Calopogonium muconoides dan P3: Stenotaphrum secundatum + Brachiaria humidicola + Pueraria javanica + Centrocema pubescens). Hasil penelitian menunjukkan bahwa bahan kering pastura tidak memberikan pengaruh yang berbeda nyata pada tingkat naungan dan level pemupukan. Hasil bahan kering paling tinggi terdapat pada N2T1P1 yaitu sebesar 17.065,60 kg/ha/tahun. Sementara itu, kandungan protein kasar memberikan pengaruh yang berbeda nyata, dimana kandungan protein kasar paling tinggi terdapat pada perlakuan N2T1P1 yaitu sebesar 19,51\%. Serat kasar memberikan pengaruh yang berbeda nyata, dimana kandungan serat kasar paling tinggi terdapat pada perlakuan N0T0P2 yaitu sebesar 42,49\%. Lemak kasar memberikan pengaruh berbeda nyata, dimana lemak kasar paling tinggi terdapat pada perlakuan N2T1P1 yaitu sebesar 4,07\%.
\end{abstract}

Kata kunci: Produktivitas pastura, pastura campuran, naungan, pemupukan, kandungan nutrisi 


\section{PENDAHULUAN}

Ketersediaan lahan yang dapat digunakan untuk pengem-bangan hijauan pakan ternak secara ekstensif kian berkurang seiring dengan bertambahnya populasi penduduk. Kenyataan diabaikannya penyediaan lahan untuk peternakan memang tidak dapat dipungkiri lagi. Sementara itu kebutuhan ternak ruminansia akan ketersediaan hijauan juga meningkat untuk pemenuhan masyarakat akan pangan. Luasnya areal perkebunan sawit di Indonesia memungkinkan untuk memanfaatkan lahan selanya untuk pengembangan budidaya rumput sebagai hijauan pakan ternak (integrasi). Namun kenyataan pengembangan secara terintegrasi ini menghadapi kendala. Kebanyakan rumput tropis kecuali yang tahan naungan meskipun kebutuhan nutrien dan airnya terpenuhi, produksi akan rendah apabila tumbuh pada tempat ternaungi dibandingkan dengan yang mendapatkan penyinaran penuh (Wilson, 1982).

Naungan adalah suatu bahan yang digunakan untuk mengurangi atau menghambat panas atau sinar matahari yang langsung ke tanaman. Untuk meningkatkan kelembaban suhu atau mengurangi penguapan disekitar tanaman oleh sinar matahari maka perlu adanya penauangan.

Pupuk secara umum ialah suatu bahan yang bersifat organik ataupun anorganik, bila ditambah kedalam tanah atau ke tanaman, dapat memperbaiki sifat fisik, sifat kimia, sifat biologi tanah dan dapat meningkatkan pertumbuhan tanaman. Sementara itu, pemupukan adalah metode atau cara-cara pemberian pupuk atau aplikasi pupuk ke dalam tanah atau ke tanaman melalui daun atau bagian tanaman lainnya (Damanik, 2011).

Pertanaman campuran rumput dan leguminosa merupakan salah satu upaya penyediaan hijauan pakan yang berkualitas dan kontinyu untuk menopang produktivitas ternak ruminansia. Rumput yang mempunyai sifat tumbuh merayap dan mempunyai laju pertumbuhan sejalan dengan leguminosa merupakan pasangan yang tepat untuk pertanaman campuran yang digembalai oleh ternak. Hal yang harus diperhatikan dari pertanaman campuran rumput leguminosa adalah toleransi atau tidaknya tanaman tersebut pada naungan.

Tujuan penelitian ini dilakukan untuk mengetahui pengaruh berbagai tingkat naungan, pemupukan, dan pastura campuran terhadap produktivitas pastura bahan kering dan kandungan nutrisi. 


\section{BAHAN DAN METODE PENELITIAN}

\section{Waktu dan Tempat Penelitian}

Penelitian telah selesai dilaksanakan di lahan komplek SNAKMA Muhamadyah di Tanjung Anom, Kecamatan Pancur Batu, Kabupaten Deli Serdang. Dengan ketinggian 25 meter diatas permukaan laut. Penelitian berlangsung selama kurang lebih 3 bulan yang dimulai bulan juni 2012 sampai dengan November 2012.

\section{Materi dan Alat Penelitian}

Bahan yang digunakan antara lain: Pastura campuran yang terdiri dari Stenopaphrum secundatum, Calopogonium muconoides, Centrosema pubescens, Arachis glabrata, Brachiaria humidicola, Pueraria javanica. Lahan yang teridiri dari 72 plot, dimana setiap plot berukuran 1,5 x 1,5 meter dengan jumlah 3-4 tanaman setiap plot. Paranet dengan kerapatan 1,7 mm dan 0,2 $\mathrm{mm}$ sebagai naungan. Pacak untuk penyanga paranet. Kawat untuk mengikat ujung dari setiap paranet. Pupuk sebagai zat hara untuk hijauan.

\section{Metode Penelitian}

Penelitian dilakukan dengan menggunakan Rancangan Petak-petak Terbagi (Split-split Plot) dengan 3 kelompok:

Faktor pertama naungan paranet sebagai petak utama dengan tiga naungan, masingmasing adalah:

N0 = tanpa paranet

$\mathrm{N} 1=$ paranet dengan kerapatan $1,7 \mathrm{~mm}$

$\mathrm{N} 2=$ paranet dengan kerapatan $0,2 \mathrm{~mm}$

Faktor kedua sebagai anak petak adalah Pemupukan (T) dengan dua taraf yaitu:

T0 = tanpa pemupukan

$\mathrm{T} 1=100 \mathrm{~kg}$ Urea $+50 \mathrm{~kg} \mathrm{SP}-36+50 \mathrm{~kg} \mathrm{KCl}$ per hektar

Faktor ketiga pastura campuran sebagai anak-anak petak merupakan kombinasi antara jenis rumput dan leguminosa yaitu:

P0 $=$ Penutup tanah konvensional Arachis glabrata + Calopogonium muconoides + Centrocema pubescens

$\mathrm{P} 1=$ Stenotaphrum secundatum + Brachiaria humidicola + Peuraria javanica + Arachis glabrata

$\mathrm{P} 2=$ Stenotaphrum secundatum + Brachiaria humidicola + Peuraria javanica + Calopogonium muconoides 
P3 = Stenotaphrum secundatum + Brachiaria humidicola + Peuraria javanica + Centrocema pubescens

Data-data yang didapat kemudian dianalisis dengan menggu-nakan rumus :

$$
Y_{i j k}=\mu+K_{l}+A_{i}+Y_{i l}+B_{j}+(A B)_{i j}+\delta_{i j l}+C_{k}+(A C)_{i k}+(B C)_{j k}+(A B C)_{i j k}+\varepsilon_{i j k l}
$$

\section{Parameter Penelitian}

\section{Produksi Bahan Kering}

Produksi bahan kering diperoleh dari produksi bahan segar dari setiap pemotongan umur 4 minggu, setelah pemotongan dilakukan penimbangan tiap petak percobaan. Dari penimbangan tersebut akan didapatkan data dari produksi segar. Kemudian sampel dioven untuk mendapatkan bobot kering dan analisis kandungan nutrien pastura.

\section{Produksi Nutrien Pastura}

Analisis kandungan nutrien pastura berdasarkan analisis proximat (PK, SK dan LK) dilakukan di Laboratorium Bahan Pakan Ternak Program Studi Peternakan Fakultas Pertanian Universitas Sumatera Utara

\section{HASIL DAN PEMBAHASAN}

\section{Bahan Kering}

Hasil penelitian dihitung dalam bentuk bahan kering yang diperoleh dari analisis proksimat dari hasil panen segar pastura campuran. Dengan analisis proksimat rataan produksi bahan kering, diperoleh hasil seperti yang tercantum dalam Tabel 1. Hasil analisis ragam pada Tabel 1 menunjukkan bahwa tidak ada pengaruh naungan terhadap produksi bahan kering. Hal ini menunjukkan bahwa pastura P0, P1, P2 dan P3 dapat tumbuh pada naungan N1, N2, dan N3. Hal ini sesuai dengan pernyataan Levitt (1980) yang menyatakan bahwa kemampuan adaptasi tanaman pada kondisi naungan sangat ditentukan oleh kemampuan tanaman untuk menghindar maupun untuk mentolerir keadaan kurang cahaya tersebut. Karakter fotosintetik tanaman yang dapat tumbuh dengan baik pada intensitas cahaya rendah berbeda dengan tanaman yang tidak dapat menyesuaikan diri pada kondisi ternaungi. Pada tanaman yang toleran, intensitas cahaya yang rendah dapat diatasi antara lain dengan meningkatkan kandungan pigmen perkloroplas. Disamping itu, tanaman toleran dapat beradaptasi dengan menghindari penurunan aktivitas enzim. 
Tabel 1. Rekapitulasi data rataan produksi bahan kering (kg/ha/tahun).

\begin{tabular}{|c|c|}
\hline Naungan $(\mathrm{N})$ & Rataan naungan \\
\hline NO & $13.826,18^{\AA}$ \\
\hline $\mathrm{N} 1$ & $13.650,99^{\mathrm{A}}$ \\
\hline $\mathrm{N} 2$ & $14.830,19^{\mathrm{A}}$ \\
\hline Pemupukan (T) & Rataan pemupukan \\
\hline T0 & $13.790,95^{\mathrm{A}}$ \\
\hline $\mathrm{T} 1$ & $14.413,95^{\mathrm{A}}$ \\
\hline Pastura campuran $(\mathrm{P})$ & Rataan Pastura campuran \\
\hline $\mathrm{P} 0$ & $13.526,55^{\mathrm{A}}$ \\
\hline $\mathrm{P} 1$ & $14.051,15^{\mathrm{A}}$ \\
\hline $\mathrm{P} 2$ & $14.256,31^{\mathrm{A}}$ \\
\hline $\mathrm{P} 3$ & $14.575,79^{\mathrm{A}}$ \\
\hline
\end{tabular}

Keterangan: Notasi sama menunjukkan tidak berpengaruh beda nyata

Perlakuan pastura P0, P1, P2, dan P3 dari Tabel 1 menunjukkan bahwa produksi bahan kering tidak menunjukkan produksi perbedaan nyata $(\mathrm{P}>0,05)$. Kecenderungan yang terjadi adalah pastura P3 (Stenotaphrum secundatum + Brachiaria humidicola + Pueraria javanica + Centrocema pubescens) lebih unggul yaitu $14.830,19 \mathrm{~kg} / \mathrm{ha} /$ tahun dari pada P0, P1, P2. Hal ini sesuai dengan pernyataan Mansyur (2005) yang menyatakan bahwa salah satu keuntungan pertanaman campuran dapat meningkatkan produktivitas lahan per satuan luas. Pola pertanaman percampuran antara rumput dan leguminosa menghasilkan peningkatan produksi hijauan dibandingkan dengan pertanaman monokultur. Namun meningkatnya persentase penanaman leguiminosa pada pola pertanaman campuran tersebut mengakibatkan penurunan produksi hijauan. Hal ini terjadi karena produksi hijauan yang dihasilkan oleh leguminosa lebih rendah dari produksi hijauan yang dihasilkan oleh rumput. Hasil penelitian menunjukkan bahwa Brachiaria sp. merupakan rumput yang baik untuk pertanaman tunggal atau dicampur dengan legum Centrosema pubescens dan Peuraria javanica.

Stenotaphrum merupakan tanaman tahunan yang menjalar, menyebar dengan stolon dan rhizoma dan membentuk hamparan padat, tanaman ini di tanam dengan menggunakan stek dan berguna untuk pencegahan erosi. Beradaptasi di daerah tropika dan sub tropika. Merupakan rumput penggembalaan yang produktif untuk daerah rendah yang lembab (Mc Ilroy, 1976).

Tabel 1 menunjukkan bahwasanya pemupukan tidak berpengaruh beda nyata $(\operatorname{Pr}>0,05)$ dengan produksi bahan kering. Hal ini menunjukkan bahwasanya kecenderungan yang terjadi adalah produksi bahan kering tetap menunjukkan peningkatan pada T1(100 kg Urea $+50 \mathrm{~kg}$ SP-36 + $50 \mathrm{~kg} \mathrm{KCl}$ per hektar) dibandingkan T0 (tanpa pemupukan). Hal ini sesuai 
pernyataan Kirychuck (2002) bahwa pupuk nitrogen dapat meningkatkan jumlah tanaman penutup tanah, terutama tanaman merambat, dimana tanaman merambat tersebut dapat menurunkan erosi, mengurangi gulma. Pupuk nitrogen dibutuhkan oleh tanaman, dimana kekurangan unsur $\mathrm{P}, \mathrm{K}$, dan $\mathrm{S}$ dapat menjadi pembatas bagi tanaman untuk menggunakan $\mathrm{N}$.

Sementara perlakuan interak-si antara naungan, pemupukan dan pastura tidak menunjukkan perbedaan nyata $(\mathrm{P}>0,05)$ terhadap produksi bahan kering.

\section{Kandungan Nutrisi}

\section{Protein Kasar}

Dari hasil panen I, II, dan III kandungan protein kasar didapat melalui analisis proksimat, sehingga didapat rataan protein kasar sebagai berikut:

Tabel 2. Rekapitulasi data rataan produksi kandungan protein kasar (\%).

\begin{tabular}{cc}
\hline Naungan $(\mathrm{N})$ & Rataan naungan \\
\hline N0 & $17,60^{\mathrm{C}}$ \\
N1 & $18,18^{\mathrm{B}}$ \\
N2 & $18,94^{\mathrm{A}}$ \\
\hline Pemupukan (T) & Rataan pemupukan $^{\mathrm{B}}$ \\
\hline T0 & $17,97^{\mathrm{B}}$ \\
T1 & $18,51^{\mathrm{A}}$ \\
\hline Pastura campuran (P) & Rataan Pastura campuran \\
\hline P0 & $18,24^{\mathrm{B}}$ \\
P2 & $18,18^{\mathrm{C}}$ \\
P3 & $18,18^{\mathrm{C}}$ \\
\hline
\end{tabular}

Keterangan: Notasi sama menunjukkan tidak berpengaruh beda nyata

Hasil analisis ragam pada Tabel 2 menunjukkan bahwa adanya perbedaan nyata $(\mathrm{P}<0,01)$ pada pengaruh naungan terhadap kandungan protein kasar $(\mathrm{N} 0, \mathrm{~N} 1$, dan $\mathrm{N} 2)$. Semakin tinggi tingkat naungan maka protein kasarnya semakin meningkat. Kemampuan tanaman untuk beradaptasi terhadap kondisi naungan ditentukan oleh kemampuannya untuk dapat melakukan fotosintesis secara normal pada keadaan kekurangan cahaya. Keadaan ini menyebabkan daun kelihatan lebih hijau pada kondisi ternaungi karena kroloplasnya mengumpul pada permukaan daun (Myers et al., 1997).

Dari pastura yang diteliti (Tabel 2) menunjukkan bahwa P3(Stenotaphrum secundatum + Brachiaria humidicola + Pueraria javanica + Centrocema pubescens) memberikan hasil produksi kandungan protein kasar yang lebih besar yaitu 18,35\%, hal ini menunjukkan 
bahwasanya pastura P3 menunjukkan pengaruh yang berbeda nyata $(\mathrm{P}<0,01)$ terhadap kandungan protein kasar.

Bila dilihat dari pengaruh pemupukan (Tabel 2) terhadap kandungan protein kasar pastura terlihat bahwa pemupukan memberikan pengaruh yang nyata $(\mathrm{P}<0,01)$ terhadap kandungan protein yaitu pada T1 sebesar 18,51\%. Hal ini sesuai pernyataan Reksohadiprodjo (1994) untuk rumput pupuk $\mathrm{N}$ yang sesuai yaitu 100-1800 kg/ha, sedangkan untuk leguminosa $100-200 \mathrm{~kg} \mathrm{~N} /$ ha.

Gambar 1 menunjukkan bahwasanya pastura yang tahan terhadap naungan dan pemupukan yang tinggi adalah interaksi N2T1P1 dengan kandungan protein kasar yaitu 19,51\%. Hal ini sesuai dengan Wilson (1982) menyatakan bahwa naungan dapat mempengaruhi nilai nutrisi pada pastura, antara lain: rendahnya tingkat karbohidrat terlarut tanaman, meningkatnya kandungan silika dan lignifikasi, menurunnnya kecernaan dinding sel, menurunnya proporsi jaringan mesophil yang mudah dicerna terhadap jaringan epidermis yang sulit dicerna, meningkatnya persentase kandungan air dari jaringan yang dapat menurunkan konsumsi hijauan oleh ternak, dan protein kasar terkadang lebih tinggi pada tanaman yang berada dibawah naungan.

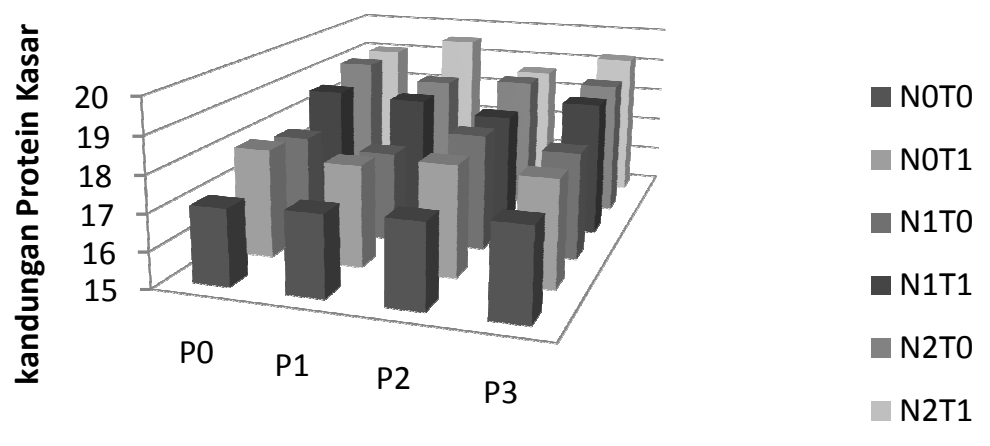

Interaksi naungan, pemupukan dan pastura

Gambar 1. Diagram batang rataan protein kasar pada pengaruh interaksi naungan, pemupukan dan pastura

\section{Serat Kasar}

Perlakuan yang bebeda diperoleh bahwa adanya kandungan serat kasar pada tiap pastura campuran dalam penelitian sehingga tiap jenis tanaman dalam pastura campuran dalam penelitian sehingga tiap jenis tanaman dalam pastura tersebut saling berusaha mencari cahaya dan hara dalam tanah. Dari hasil panen I, II, dan III kandungan protein kasar didapat melalui analisis proksimat, sehingga didapat rataan serat kasar sebagai berikut: 
Tabel 3. Rekapitulasi data rataan produksi kandungan serat kasar (\%).

\begin{tabular}{cc}
\hline Naungan $(\mathrm{N})$ & Rataan naungan \\
\hline N0 & $42,33^{\mathrm{A}}$ \\
N1 & $40,31^{\mathrm{B}}$ \\
N2 & $38,61^{\mathrm{A}}$ \\
\hline Pemupukan (T) & Rataan pemupukan $^{\mathrm{A}}$ \\
\hline T0 & $40,52^{\mathrm{A}}$ \\
\hline T1 & $40,32^{\mathrm{B}}$ \\
\hline Pastura campuran (P) & Rataan Pastura campuran \\
\hline P1 & $40,30^{\mathrm{C}}$ \\
P2 & $40,43^{\mathrm{B}}$ \\
P3 & $40,18^{\mathrm{D}}$ \\
\hline
\end{tabular}

Keterangan: Notasi sama menunjukkan tidak berpengaruh beda nyata

Dari hasil sidik ragam Tabel 3 menunjukkan perbedaan nyata $(\mathrm{P}<0,01)$ terhadap serat kasar, dimana perlakuan tanpa naungan (N0) menunjukaan hasilnya yang paling tinggi yaitu sebesar 42,33\%. Hal ini sesuai dengan pernyataan Siregar (1988) bahwasanya varietas hijauan pakan ternak tidak mempunyai nilai gizi yang sama. Hal ini diakibatkan oleh faktorfaktor yang mempengaruhinya yaitu jenis dan umur tanaman yang berbeda-beda. Kadar protein, mineral dan karbohidrat akan menurun dengan meningkatnya umur tanaman, sedangkan serat kasar dan lignin akan bertambah.

Perlakuan pastura campuran (Tabel 3) memperlihatkan pengaruh yang beda nyata $(\mathrm{P}<0,01)$, dimana terlihat P3 (Stenotaphrum secundatum + Brachiaria humidicola + Pueraria javanica + Centrocema pubescens) menunjukkan hasil yang lebih baik dari P0, P1, dan P3 yaitu sebesar 40,76\%/petak. Hal ini sesuai pernyataan bahwa Brachiaria sp. Merupakan rumput yang baik untuk pertanaman tunggal atau dicampur dengan legum Centrosema pubescens. Interval 6-8 minggu menghasilkan produksi yang maksimum. Sebaiknya dipergunakan sebagai rumput potongan untuk makanan ternak, dan kalaupun harus untuk penggembalaan sebaiknya dilakukan dengan rotasi karena rumput ini tidak tahan untuk penggembalaan berat, sebaiknya di pupuk dengan N 200-400 kg/ha/tahun (Reksohadiprodjo, 1994). Stenotaphrum merupakan tanaman tahunan yang menjalar, menyebar dengan stolon dan rhizoma dan membentuk hamparan padat, tanaman ini di tanam dengan menggunakan stek dan berguna untuk pencegahan erosi. Beradaptasi di daerah tropika dan sub tropika. Merupakan rumput penggembalaan yang produktif untuk daerah rendah yang lembab (Mc Ilroy 1976).

Pada pemupukan (T) Tabel 3 menunjukkan pengaruh yang nyata $(\mathrm{P}<0,01)$ terhadap kandungan serat kasar. Perlakuan T0 (tanpa pemupukan) menunjukkan hasil yang lebih tinggi dibandingkan T1 yaitu sebesar 40,52\%. 
Interaksi naungan $(\mathrm{N})$, pemupukan $(\mathrm{T})$ dan pastura campuran $(\mathrm{P})$ menunjukkan pengaruh yang nyata $(\mathrm{P}<0,01)$ terhadap serat kasar (Gambar 2). Perlakuan N0T0P2 menunjukkan rataan serat kasar lebih tinggi yaitu 42,49\%. Hal ini menunjukkan bahwa kandungan serat kasar P2 lebih baik pada perlakuan tanpa naungan dan tanpa pemupukan.

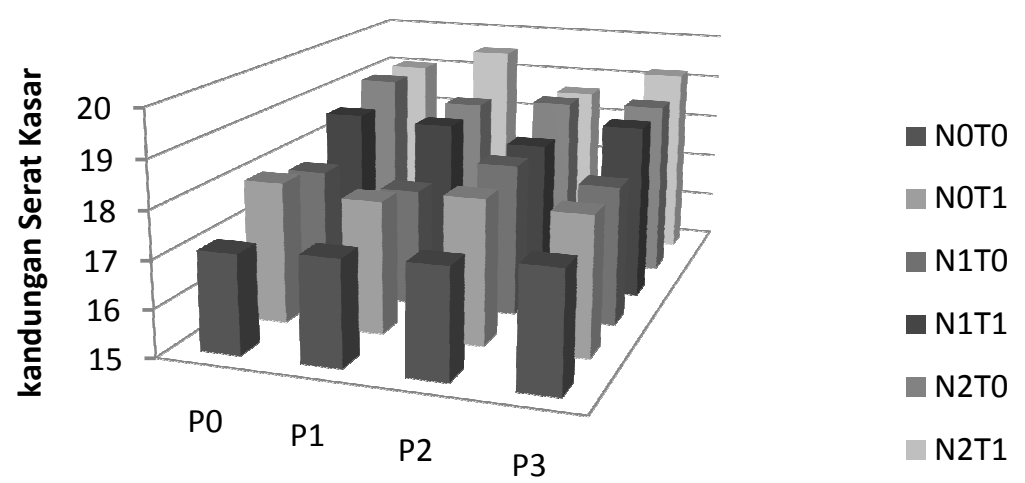

Interaksi naungan, pemupukan dan pastura

Gambar 2. Diagram batang rataan serat kasar pada pengaruh interaksi naungan, pemupukan dan pastura

\section{Lemak Kasar}

Dari hasil bahan kering yang diperoleh kandungan lemak kasar melalui analisis proksimat. Data hasil pengamatan terhadap kandungan lemak kasar pastura disajikan pada Tabel 4.

Perlakuan naungan padaTabel 4 menunjukkan pengaruh nyata $(\mathrm{P}<0,01)$ terhadap kandungan lemak kasar. Pada uji duncan terlihat N0 dan N2 berbeda nyata dengan N1. Perlakuan N2 menunjukkan pengaruh yang lebih baik yaitu 3,36\%. Hal ini sesuai dengan pernyataan sebagian besar spesies rumput tropis mengalami penurunan produksi sejalan dengan menurunnya intensitas sinar (Ludlow 1978), namun spesies yang tahan terhadap naungan sering menunjukkan penurunan produksi yang relatif kecil atau masih meningkat pada naungan sedang (Wong et al. 1985; Samarakoon et al. 1990).

Tabel 4. Rekapitulasi data rataan produksi kandungan lemak kasar (\%).

\begin{tabular}{cc}
\hline Naungan (N) & Rataan naungan \\
\hline N0 & $3,36^{\mathrm{A}}$ \\
N1 & $3,21^{\mathrm{B}}$ \\
N2 & $3,36^{\mathrm{A}}$ \\
\hline Pemupukan (T) & Rataan pemupukan \\
\hline
\end{tabular}




\begin{tabular}{cc}
\hline T0 & $2,91^{\mathrm{B}}$ \\
T1 & $3,71^{\mathrm{A}}$ \\
\hline Pastura campuran (P) & Rataan Pastura campuran \\
\hline P0 & $3,37^{\mathrm{A}}$ \\
P1 & $3,35^{\mathrm{A}}$ \\
P2 & $3,33^{\mathrm{A}}$ \\
P3 & $3,19^{\mathrm{B}}$ \\
\hline
\end{tabular}

Keterangan: Notasi sama menunjukkan tidak berpengaruh beda nyata

Pastura campuran (P0,P1,P1 dan P3) yang terlihat pada Tabel 4 menunjukkan pengaruh yang nyata $(\mathrm{P}<0,01)$ terhadap kandungan lemak kasar. Perlakuan P1 (Arachis glabrata + Calopogonium muconoides + Centrocema pubescens) menunjukkan kandungan lemak kasar yang paling tinggi yaitu 3,37\%. Hal ini sesuai dengan pernyataan Reksohadiprodjo (1994) bahwasanya legum Centrosema pubescens termasuk sub-familia Papilionaceae dari familia Leguminoceae. Spesies ini berasal dari Amerika Selatan dan telah ditanam dengan hasil baik di daerah-daerah tropik dan sub tropik. Daun-daun Centro adalah lebih runcing bila dibandingkan dengan daun-daun legum Puero atau Calopo. Sifat tumbuh Centro adalah parennial (hidup lebih dari satu tahun), sangat agresif, batang-batangnya menjalar dan membentuk pertanaman penutup tanah 4 sampai 6 bulan sesudah penanaman biji. Centro berdaun lebat dan batangnya tidak berkayu meskipun tanaman telah berumur 18 bulan. Legum ini tahan terhadap tanah kering dan bila pertanaman telah berhasil terjadi, maka akan tahan hidup di bawah naungan.

Gambar 12 menunjukan bahwa interaksi antara naungan $(\mathrm{N})$, Pemupukan $(\mathrm{T})$, dan pastura campuran (P) menunjukkan pengaruh yang sangat nyata $(\mathrm{P}<0,01)$ terhadap kandungan lemak kasar. Dimana interaksi N2T1P1 menghasilkan lemak kasar paling yaitu 4,07\%. Hal ini menunjukan bahwa P1 (Stenotaphrum secundatum + Brachiaria humidicola + Pueraria javanica + Arachis glabrata) menghasilkan lemak yang baik pada perlakuan T1 $(100 \mathrm{~kg}$ Urea $+50 \mathrm{~kg} \mathrm{SP}-36+50 \mathrm{~kg} \mathrm{KCl}$ per petak) dan N2 (paranet 0,2 mm). 


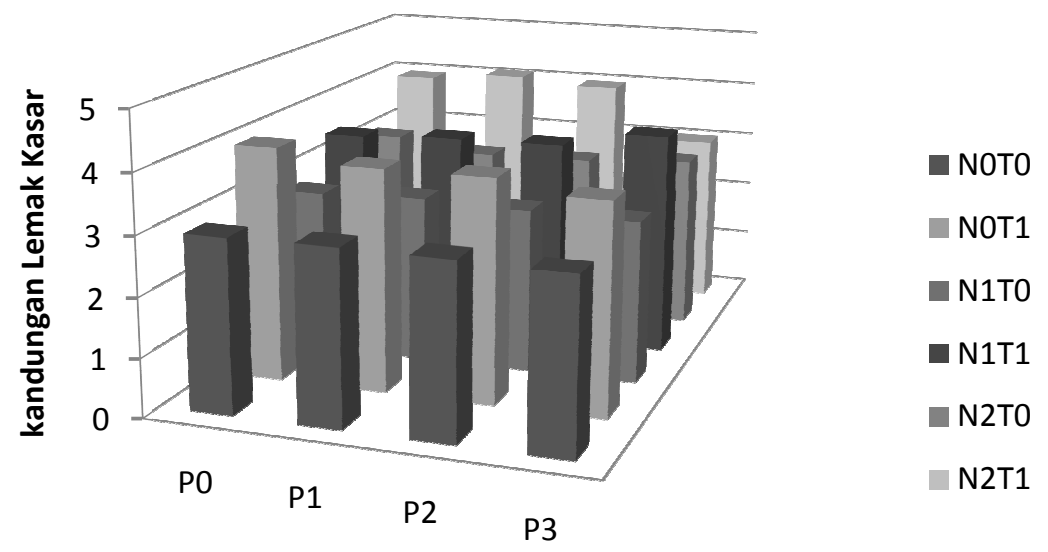

Interaksi naungan, pemupukan dan pastura

Gambar 3. Diagram rataan lemak kasar pada pengaruh interaksi naungan.

\section{KESIMPULAN}

Kesimpulan dari hasil penelitian ini adalah :

1. Produksi bahan kering dan kapasitas tampung pada perlakuan naungan, tingkat pemupukan dan pastura tidak memberikan pengaruh yang nyata. Karena pastura campuran (P0, P1, P2 dan P3) tumbuh pada naungan rendah sampai dengan tinggi (tanpa paranet, paranet dengan kerapatan 1,7 $\mathrm{mm}$ dan paranet dengan kerapatan 0,2 $\mathrm{mm}$ ) dan pada kondisi tanpa pemupukan atau pemupukan (T0 dan T1).

2. Kandungan nutrisi pastura pada perlakuan tingkat naungan, level pemupukan dan pastura campuran memberikan pengaruh yang berbeda nyata.

- Protein kasar menunjukkan bahwasanya semakin tinggi tingkat naungan (N2) maka kandungan protein kasarnya semakin tinggi, semakin tinggi level pemupukan (T1) maka protein kasar akan semakin tinggi dan protein kasar lebih tinggi pada kombinasi P3 (Stenotaphrum secundatum + Brachiaria humidicola + Pueraria javanica + Centrocema pubescens).

- Serat kasar menunjukkan bahwasanya semakin rendah tingkat naungan (N0) maka akan semakin tinggi serat kasarnya, semakin rendah level pemupukan (T0) makan serat kasar akan semakin tinggi, dan serat kasar lebih tinggi pada kombinasi P3 (Stenotaphrum secundatum + Brachiaria humidicola + Pueraria javanica + Centrocema pubescens) karena rumput lebih dominan dan memiliki serat kasar yang tinggi. 
- Lemak kasar menunjukkan bahwasanya semakin tinggi tingkat naungan (N2) maka akan semakin tinggi lemak kasarnya, semakin tinggi level pemupukan (T1) makan lemak kasar akan semakin tinggi dan lemak kasar lebih tinggi pada kombinasi P0 (Arachis glabrata + Calopogonium muconoides + Centrocema pubescens).

\section{DAFTAR PUSTAKA}

Damanik, M. Madjid B. et al. 2011. Kesuburan Tanah dan Pemu-pukan. USU Press, Medan.

Kirychuck B, et al. 2002. Rejuvenation of Tame Forages. The Canada Saskatchewan AgriFood Innovation Fund: 18-19.

Levitt J. 1980. Response of Plants to Enviromental Stress. Academic Press. New York.

Mansyur, L. Abdullah., H. Djuned, dan T. Dhalika, 2005. Perubahan dalam hasil panen dan kandungan fraksi serat pada tingkat umur pemotongan rumput setaria. Jurnal Ilmu-ilmu Peternakan. Volume 8. Edisi khusus. 29 - 36.

McIlroy, R. J. 1976. Pengantar Budidaya Padang Rumput Tropika. Pradnya Paramita, Jakarta . (Diterjemahkan oleh S. Susetyo, Soedarmadi, I. Kismono dan S. Harini I. S.).

Myers DA, DN Jordan, TC Vogerman. 1997. Inclination of Sun and Shade Leaves Influenced Chloroplast Light Harvesting and Utilizatin. Plant Physiol 99: 395- 404.

Reksohadiprodjo,S.1994. Produksi Tanaman Hijauan Makanan Ternak Tropika. Yogyakarta: BPFE,

Samarakoon SP, JR Wilson, Shelton. 1990. Growth, marphologi and nutritive quality of shaded Stenotaphrum secundatum, Axonopus compressus and Pennisetum clandestinum.

Siregar ME. 1988. Apa Itu King Grass. Jakarta: Dirjen Peternakan Departemen

Whitehead DC. 2000. Nutrient Element in Grassland: Soil-Plant-Animal Relationship. United Kingdom: CAB International.

Wong CC,. MA. Mohd. Sharudin, dan H Rahim., 1985. Shade Tolerance Potential of Some Tropical Forages for Integration with Plantations. Mardi Research Bull.

Wilson JR. 1982. Enviromental and nutritional factor affecting herbage quality. United Kingdom. p.111-131. 